\title{
Morphometric Evaluation of Epithelial Mucosa by the Maxillary Sinus at Sinusitis
}

\author{
Yu. M. Andreychyn, Yu. Orel \\ I.Ya. Horbachevsky Ternopil State Medical University \\ Recension - Doc. Georgi Marinov - Sofia
}

\begin{abstract}
Summary:
The results of morphometric researches of parameters of epiteliocitiv are resulted in the imprints of mucus shell of genyantrum in 41 patient with a sharp and chronic supramaxillary sinuitis. A control group was made 10 patients with the breaks of supramaxilla. Found out the increase of volume of cages at a sharp sinuitis and diminishing of this index and growth of nucleocytoplasmic index - at a chronic sinuitis.
\end{abstract}

Keywords: maxillary sinusitis, epithelial cells, morphometric parameters.

\section{Introduction}

In nosological structure of otolaryngology disease sinusitis is in second place. [14] Most diseases accounted for maxillary sinusitis [3]. However, despite significant advances in diagnosis and treatment of acute and chronic sinusitis, the current rating of the course and the proposed combined therapy should be improved.

One of the generally accepted measures of local inflammatory reaction are histological, histochemical and electronmicroscopic study of mucosal biopsy [7, 8]. Valuable data obtained in the description of the cellular composition of reflections affected membrane [2]. The subjective factor is affect in the evaluation describe of morphological changes affect. Therefore, often used to morphometric researches, but they are not used by sinusitis.

The objective of the investigation is to investigate the morphometric parameters epithelial mucosa maxillary sinus in acute and chronic inflammation.

\section{Materials and methods}

Was stained a cytology imprints mucosa (by Romanovsky-Gimsa) of the maxillary sinus in acute (14 patients) and chronic (27 patients), maxillary sinusitis. The age of patients ranged from 18-69 years, men were 20 , women -21 . Comparison group consisted of 10 patients of similar age with bone fractures of the upper jaw without prior otolaryngology pathology in history. During morphometric study of imprints epithelial cells were determined by the following parameters: short and long diameters of cells, cell area, long and short diameters of the core area of the nucleus, cytoplasm, 
cell volume, the cytoplasm and nucleus, nuclearcytoplasma index [1].

\section{Results and discussion}

At the turn of bone imprints sinus mucosa observed cytology alternative acute changes (Fig. 1). Among cells were desquamated epithelial cells, was also numerous population of lymphocytes.

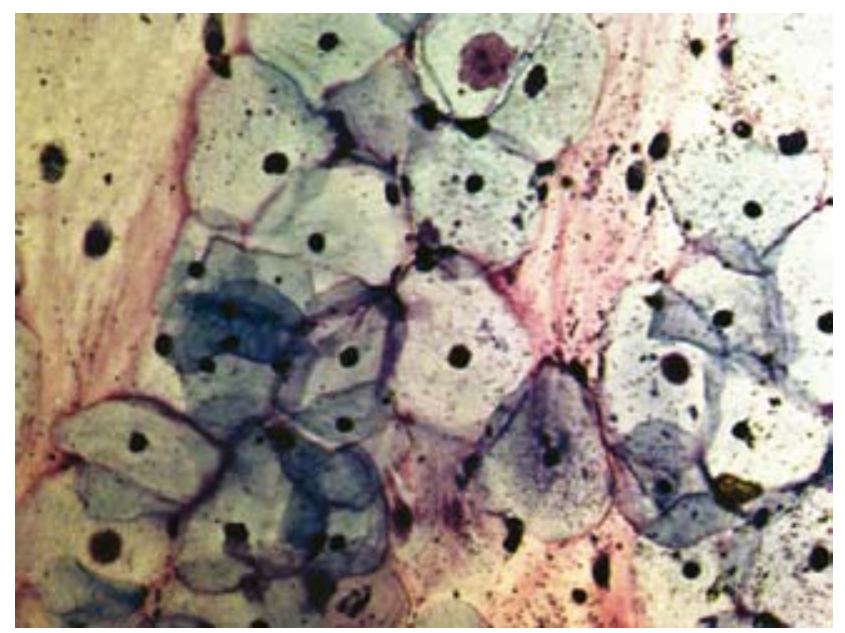

Figure. 1. Elements of the cells of the surface layer of the maxillary sinus trauma.

Coloring by Romanovsky-Gimsa. Ok. 10, vol. 40 .

In acute maxillary sinusitis (Fig. 2) the number of imprints epithelial cells decreased, but was large enough, which is probably due to the nature of catarrhal inflammation. Significantly increased number of neutrophils leukocytes, among which came degenerative altered cells. Active migration of neutrophils can be considered as a marker of the early stage of purulent forms of acute sinusitis. Share fibroblasts among relative comparison group

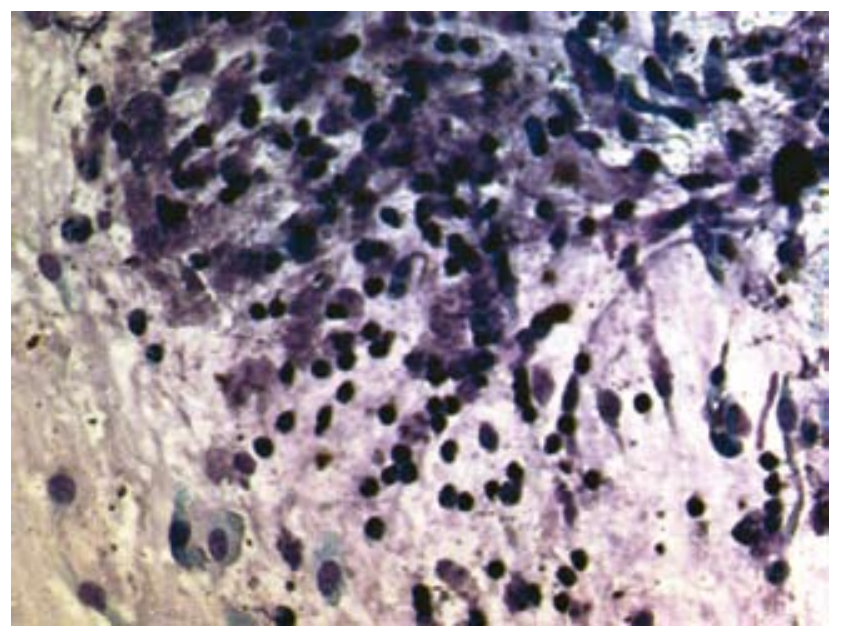

Figure. 2. Elements of the cells of the surface layer of the maxillary sinus in acute sinusitis.

Coloring Romanovsky-Gimsa. Ok. 10, vol. 40. are not changed. Increased number of lymphocytes and plasma is indicated the important role of immune disturbances in the development of acute maxillary sinusitis. About allergic factor is indicat a significant increase in population of labrosits.

The cells which are present in chronic maxillary sinusitis were fibroblasts (Fig. 3), meanwhile imprints epithelial cells were significantly decreasing. They were modified with enlarged nuclei, indistinct outline and hyperchromatic karioplazma. In a population of lymphocytes observed negative dynamics. Number of plasmocite and labrocyte were increased in relation to the comparison group, but it did not reach the number that observed in acute inflammation.

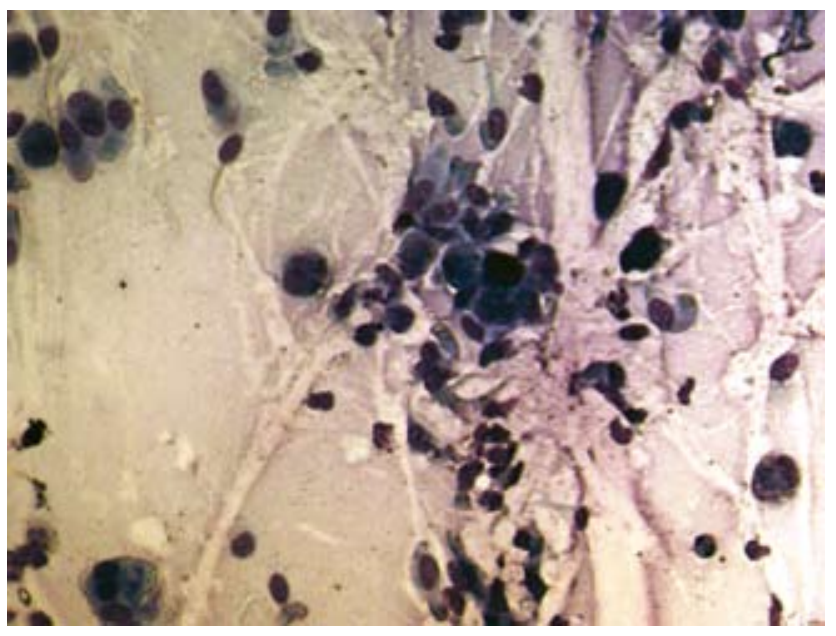

Figure. 3. Elements of the cells of the surface layer of the maxillary sinuses in chronic sinusitis.

Coloring Romanovsky-Gimsa. Ok. 10, vol. 40.

Was established cytometric parameters epithelial mucosa of the maxillary sinus, which defined is alteration in acute and chronic inflammation. The results are presented in table 1.

By acute sinusitis diameters of imprints epithelial cells were change no significantly - short diameter decreased by $2.75 \%$, and long increased by $9.92 \%$. In chronic sinusitis the first indicator was decrease by $20.18 \%$, the second - by $16.31 \%$, while they were different significantly from the comparison group ( $\mathrm{p}<0.001$ and $\mathrm{p}<0.01$ respectively). The area of cells were transformed along with the change in the diameter: in the first study group it increased by $17.34 \%$, while in the second regressed to $19.02 \%$, significantly differ from that seen in the comparison group $(\mathrm{p}<0.05)$.

Morphometric changes of the nucleus and cytoplasm parameters in epithelial cells were differed, as evidenced by the following indicators. The short 
Table 1

Cytometric parameters of epithelial mucosa is in maxillary sinus by various types of lesions $(\mathrm{M} \pm \mathrm{m})$

\begin{tabular}{|c|c|c|c|}
\hline \multirow[t]{2}{*}{ Parameters } & \multicolumn{3}{|c|}{ Investigated group } \\
\hline & Bone fracture, $n=10$ & Acute sinusitis, $n=14$ & Chronic sinusitis, $n=27$ \\
\hline \multicolumn{4}{|l|}{ Diameter of cells, $\mu$} \\
\hline - short & $10.9 \pm 0.4$ & $10.6 \pm 0.3$ & $8.7 \pm 0.3^{* * * \circ}$ \\
\hline - long & $14.1 \pm 0.6$ & $15.5 \pm 0.4$ & $11.8 \pm 0.5^{* * 00}$ \\
\hline Square of cells, $\mu^{2}$ & $118.8 \pm 8.0$ & $139.4 \pm 10.2$ & $96.2 \pm 7.1^{* \circ}$ \\
\hline \multicolumn{4}{|l|}{ Diameter of cells, $\mu$} \\
\hline - short & $7.1 \pm 0.3$ & $7.5 \pm 0.4$ & $8.2 \pm 0.4^{*}$ \\
\hline - long & $8.9 \pm 0.3$ & $9.2 \pm 0.5$ & $9.4 \pm 0.4$ \\
\hline Square of cells, $\mu^{2}$ & $51.0 \pm 2.4$ & $58.3 \pm 2.9$ & $59.2 \pm 3.2^{*}$ \\
\hline Square of cytoplasma, $\mu^{2}$ & $66.2 \pm 3.9$ & $80.6 \pm 4.3^{*}$ & $47.6 \pm 2.2^{\star * * \circ \circ}$ \\
\hline Volume of cells, $\mu^{3}$ & $767.0 \pm 24.8$ & $930.0 \pm 30.5^{\star * *}$ & $644.3 \pm 2.1^{* * *}$ \\
\hline Volume of nucleus, cytoplasma 3 & $230.4 \pm 14.0$ & $273.9 \pm 15.9$ & $287.1 \pm 15.1^{\star *}$ \\
\hline Volume of cytoplasma, $\mu 3$ & $538.0 \pm 22.7$ & $654.2 \pm 24.8^{* *}$ & $356.8 \pm 20.1^{* * *}$ \\
\hline Nuclear-cytoplasmic index & $42.6 \pm 2.2$ & $41.8 \pm 2.0$ & $80.4 \pm 3.7^{* * *}$ \\
\hline
\end{tabular}

diameter of core was increase by acute sinusitis in $5.63 \%$ patient, the long diameter $-3.37 \%$. Size of the nucleus was increase in chronic sinusitis essentially. Short diameter was increase by $15.49 \%$, significantly different from control values $(\mathrm{p}<0,05)$, and a long diameter increased slightly - by $5.61 \%$. The core area was change too, which in both study groups increased - by $14.31 \%$ in the first group and $16.07 \%$ in the second. Chronic sinusitis core area was significantly different from the value in the comparison group $(\mathrm{p}<0,05)$.

The cytoplasm of epithelial cells expanded in acute sinusitis by $21.75 \%$, chronic inflammation has decreased by $28.09 \%$. The difference between the values of specified rate in the comparison group and the study groups was statistically significant $-p<0.05$ for the first group and $p<0.001$ for the second.

Volume of epithelial cells was increase in acute sinusitis by $21.9 \%$, and by chronic decreased in $15.99 \%$ but the volume of the nucleus growing up in both study groups - to $18.88 \%$ in acute inflammation and to $24.60 \%$ in chronic. Volume of cytoplasm is also varied in this pathology. In acute sinusitis, this morphometric index increased by $21.59 \%$, in chronic decreased significantly - by $33.68 \%$. Most variables volume characteristics of cells were significantly different in research and control groups (Table 1).

The nuclear-cytoplasmic index significancy by bone fractures was $(42.6 \pm 2.2) \%$, in acute maxillary sinusitis almost no changed $-(41.8 \pm 2.0) \%$, but in chronic was grown at 1.92 times and it was $(80.4 \pm 3.7) \%$, $(\mathrm{p}<0,001)$.

Comparison parameters epithelial mucosa of the maxillary sinus in acute and chronic sinusitis were noteworthy. Diameter and area of these cells, their area of cytoplasm, cell volume and the cytoplasm were significantly higher in acute maxillary sinusitis $(p<0.02-0.03)$. However, both diameters of the nucleus, it's area and volume in acute and chronic inflammation did not differs $(p>0.05)$. In this value parameters our established ongoing nuclear cytoplasm index in patients with chronic maxillary sinusitis was almost twice as high than in acute sinusitis $(\mathrm{p}<0.02)$.

Morphometric parameters of epithelial cells is suggests of restructuring of the mucosa by the maxillary sinus in acute and chronic inflammation. Increasing the volume of cells in acute sinusitis is a manifestation of hyperfunction, which reflecting catarrhal component of acute inflammation. Reduction of morphometric criteria for chronic sinusitis is indicate dystrophy and atrophy in the mucosa. But growing nuclear-cytoplasmic index was shows a predominance of proliferative effects in chronic inflammation, which can be regarded as a potential risk factor for initiation of tumor.

As you know, the main role in the etiology of maxillary sinusitis is allocating diverse by microbial flora. Acute sinusitis, usually develop in patients with influenza and other acute respiratory viral infections on the background of reduced local and general immunity $[10,11,14]$, slowing or 
even stopping of the mucociliary transport [12]. Mucous membrane is colonized by association of several species of aerobic and anaerobic microbial flora during chronic sinusitis, sometimes in combination with viruses. Fungal sinusitis, which is formed on the background of the repeated courses of antibiotic therapy, is characterized by a relatively heavier flow and is very often [4]. Maxillary sinusitis have odontogenyc or rynogenic origin. Intoxication of the cells membranes with endogenous peptides that accumulate as a result of incoordination metabolic processes is also cause of the damage of a mucous membrane, accept following etiological factors [6]. Violation of aerodynamics in the nasal cavity and paranasal sinuses also helps in the development of the sinusitis [13]. Allergic component also has a significant place in the pathogenesis of sinusitis [16]. These etiologic and pathogenetic factors would cause catarrhal nature

\section{Literature}

1. Автандилов Г. Г. Основы количественной патологической анатомии - М.: Медицина. - 2002. - 240 с.

2. Gilead B., Tatiana K., Miki P., Sivan B., Yaniv Eb. Pediatric chronic rhinosinusitis histopathology differences and similarities with the adult form // Otolaryngology-Head and Neck Surgery. 2011. - N 144. - P. 85-90.

3. Seok H., Tae H., Kyung R., Lee Jong-Min, Lee Dong-Kyun Factors for maxillary sinus volume and craniofacial anatomical features in adults with chronic rhinosinusitis // Otolaryngology-Head and Neck Surgery. - 2010. - N 6. - P. 610-615.

4. Заболотний Д. І., Зарицька І. С. Клініко-рентгенологічні особливості клінічного перебігу грибкових синуситів // Ринологія. - 2004. - № 2. - С. 21-29.

5. Заболотный Д. И., Боенко Д. С. Особенности строения клиновидной пазухи: этиология, патогенез и патологическая анатомия сфеноидита // Журн. вушн., нос. і горл. хв. - 2007. - № 2. - С. 73-80

6. Заболотний Д. І., Кизим О. Й, Верьовка С. В. Патологічні ефекти інтоксикації клітинних мембран ендогенними пептидами // Журнал Національної академії медичниих наук України. 2011. - Т. 17. - № 3. - С. 201-207.

7. Захарова Г. П., Ильинская Е. В. Ультраструктура слизистой оболочки носа и околоносовых пазух у больных хроническим полипозным риносинуситом // Вестник оториноларингологии. - 2000. - № 3. - С. 40-42.

8. Ильинская Е. В., Захарова Г. П. Морфофункциональные особенности собственного слоя слизистой оболочки верхнечелюстных of acute inflammation in the affected sinuses, which may change from time in the chronic form, with its dystrophy and atrophy of the affected mucosa, including epithelial cells.

\section{Conclusions}

1. The size of the imprints mucosal cells in maxillary sinusitis clearly reflects the presence of acute or chronic inflammation, and may use as an objective criterion for differential diagnosis.

2. Analysis of morphometric parameters of the epithelial mucosa of the maxillary sinus is the increase in the volume of cells during acute sinusitis and reduction during chronic, as well as growth in the last nuclear-cytoplasmic index.

3. Morphometric study of the imprints of epithelial cells of the mucous tissue of the maxillary sinus allows to objectify the assessment of the maxillary sinusitis.

пазух при хроническом полипозном и полипозно-гнойном риносинусите // Рос. ринология. - 2002. - № 1. - С. 11-14.

9. Roni K., Gal G., Nissan J., Avital K. at all. Histomorphometric Analysis of Maxillary Sinus Augmentation Using an Alloplast Bone Substitute // Oral and Maxillofacial Surgery. - N 8. - P. 18351843.

10. Крюков А. И., Шубин М. Н. Адекватная антибиотикотерапия острого и вялотекущего риносинусита // Ринология. - 2002. № 4. - С. 48-55.

11. Лайко А. А., Горошко О. І., Молочек Ю.А. Діагностика та лікування дітей з фронтитами // Журн. ушн., нос. и горл. бол. - 1998. - № 5. - C. 64-65.

12. Andreea D., Mugurel R., Mihai S., Carmen G., Radu C. at all. Morphometric analysis of the relationships between the maxillary first molar and maxillary sinus floor // Open Journal of Stomatology. 2012. - N 2. - P. 352-357.

13. Пискунов В. С., Морозов С. А. Роль деформаций переднего отдела перегородки носа в развитии этмоидита // Журн. вушн., нос. і горл. хв. - 2001. - № 3, Додаток. - С. 140-141.

14. Пухлик С. М., Щелкунов А. П. Острые синуситы купального сезона // Ринологія. - 2009. - № 1. - С. 47-51.

15. Brook I. I., Frazier E. N., Foode P.A. Microbiology of the transition from acute to chronic maxillary sinusitis // J. Med. Microbiol. - 1996. - Vol. 45. - N 5. - P. 372-375.

16. Huang S. W. The risk of sinusitis in children with allergic rhinitis // Allergy Asthma Proc. - 2000. - Vol. 21. - N 2. - P. 85-88.

\section{Correspondence}

Ukraine, Ternopil

I.Ya. Horbachevsky Ternopil State Medical University Department of Otorhinolaryngology, Ophthalmology and Neurosurgery

Ternopil Regional Clinic Hospital

Dr. Yuriy Andreychyn, MD, Ass. Prof.

E-mail:yuralor@meta.ua 